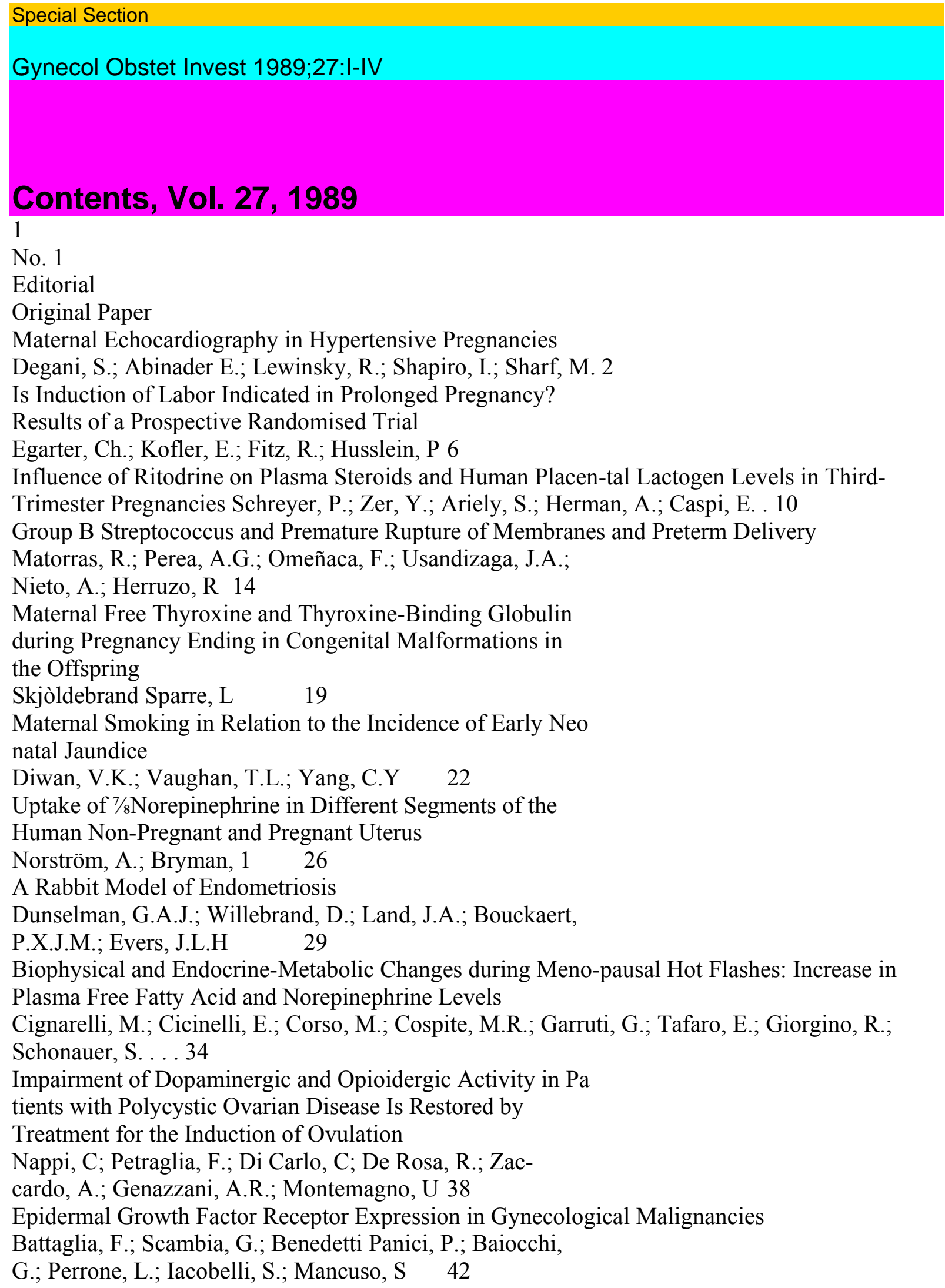




\section{Case Reports}

45, XO/46, X, $\operatorname{dic}(Y q)$ Mosaicism in Turner's Phenotype with

Endodermal Sinus Tumor of the Ovary

Ono, T.; Sakai, N.; Hayashi, Y.; Saito, M.; Kawagoe, S.;

Hiroi, M 45

Menstrual Variation of Estrogen Receptor Content in Vaginal

Tissue

Sjöberg, I.; Rylander, E.; von Schoultz, B 48

Doppler Color Flow Mapping of an Invasive Mole

Aoki, S.; Hata, T.; Hata, K.; Senoh, D.; Miyako, J.; Taka-

miya, O.; Iwanari, O.; Kitao, M 52

High-Dose Chemotherapy, Total Abdomen Irradiation and Autologous Bone Marrow Infusion in

Ovarian Cancer: An Observation

Norès, J.-M.; Dalayeun, J.-F.; Otmezguine, Y.; Folgoas, C;

Nenna, A.-D 55

No. 2

Original Paper

Characterization of Membrane Calcium Channels in Nonpreg-

nant and Pregnant Human Uterus

Batra, S.C.; Popper, L.D 57

Role of the Newborn's Sex in Mixed Maternal-Newborn Lymphocyte Culture Reactivity

Komlos, L.; Sirota, L.; Notman, J.; Dulitzky, F.; Hart, J.;

Goldman, J.; Halbrecht, $1 \quad 62$

Transcervical Chorionic Villi Sampling: A Comparison between the Silver Cannula and the

Portex Catheter Barkai, G.; Rabinovici, J.; Chaki, R.; Shalev, J.; Katz-nelson, M.B.-M.;

Mashiach, S.; Serr, D.M.; Goldman, B. . 70

Scheduled Intermittent Periods of in vitro Fertilization Treatments

Lunell, N.-O.; Åkerlòf, E.; Brody, S.; Carlström, K.; Fre-

dricsson, B.; Gustafson, O.; Nylund, L.; Rosenborg, L.;

Slotte, H.; Pousette, $\AA 74$

Diurnal Variations in Thyrotropin, Prolactin and Cortisol during Human Pregnancy

Eriksson, L.; Edén, S.; Hoist, J.; Lindstedt, G; von

Schoultz, B 78

Amoxicillin in the Treatment of Asymptomatic Bacteriuria in

Pregnancy: A Single Dose of $3 \mathrm{~g}$ Amoxicillin versus a 4-Day

Course of 3 Doses of $750 \mathrm{mg}$ Amoxicillin

Gerstner, G.J.; Müller, G; Nahler, G 84

Placenta previa and Antepartum Hemorrhage after Previous

Cesarean Section

Nielsen, T.F.; Hagberg, H.; Ljungblad, U 88

Cadmium Contamination of Early Human Milk

Sikorski, R.; Paszkowski, T.; Radomanski, T., Jr.; Szkoda, J. 91

Different Dopaminergic Control of Plasma Luteinizing Hormone, Follicle-Stimulating Hormone and Prolactin in Ovulatory and Postmenopausal Women: Effect of Ovariec-tomy

De Leo, V.; Petraglia, F.; Bruno, M.G.; Lanzetta, D.;

Inaudi, P.; D’Antona, N 94 
Ultrasonographic Identification and Measurement of the Nor mal Ovary in Postmenopausal Japanese Women Hata, K.; Hata, T.; Takamiya, O.; Kitao, M 99

Second-Look Laparotomy in Ovarian Carcinoma Patients after 8 and after 12 Courses of Cisplatin-Based Chemotherapy Menczer, J.; Ben-Baruch, G.; Modan, M.; Brenner, H. . . 102 Urethral Closure Function after Total and Subtotal Hysterec tomy Measured by Urethroxystometry Kujansuu, E.; Teisala, K.; Punnonen, R 105 IV

Contents

Case Reports

Malignant Melanoma of the Cervix

Chua, S.; Viegas, O.A.C.; Wee, A.; Ratnam, S.S 107

Lipid Cell Tumor of the Ovary: Steroid Hormone Secretory

Pattern and Localization Using 75Se-Selenomethylcholes-

terol

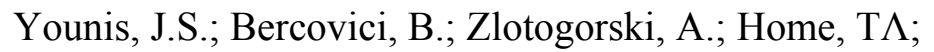

Glaser, B 110

Short Communications

Serum Cancer Antigen 125 in Ectopic Pregnancy

Sauer, M.V.; Vasilev, S.A.; Campeau, J.; Vermesh, M. . 164 Serum C-Reactive Protein Levels in Patients with Cervical

Neoplasia

Wong, F.; Arumanayagam, M.; Swaminathan, R.; Chang, A. 166

Announcement $\quad 132$

Announcement $\quad 101$

No. 4

No. 3

Original Paper

Late-Pregnancy Changes in Peripheral Plasma Beta-Endor-

phin in Rhesus Monkeys (Macaca mulatta)

Golub, M.S.; Eisele, J.H., Jr.; Hwang, F.Y.; Arbabzadeh, H. 113 Effects of Indomethacin on

Human Placental Stem Villous

Arteries

Allen, J.; Lauridsen, V.; Hansen, V.; Andersson, K.-E.; Forman, A118

Outcome of Fetuses with Abnormal Biophysical Profile

Herrmann, U., Jr.; Dürig, P.; Amato, M.; Sidiropoulos, D.;

Schneider, H 122

Studies on Amniotic Prolactin: Chromatographic Pattern and

Correlation with the Lecithin Content

Pansini, F.; Bergamini, CM.; Bagni, B.; Linciano, M.;

Condemi, L.; Bonaccorsi, G.; Vesce, F 126

The Source of Immunoglobulin E in the Fetus at Term

Schreyer, P.; Avrech, O.; Caspi, E.; Samra, Z.; Sompolin- 
sky, D 129

Effects of Human Growth Hormone upon Term Placental

Hormone Secretion in vitro

Barnea, E.R.; Perlman, R.; Bick, T.; Hochberg, Z 133

Measurement of CEA, TPA, Neopterin, CA125, CA153 and

CA199 in Sera of Pregnant Women, Umbilical Cord Blood

and Amniotic Fluid

Lellé, R.J.; Henkel, E.; Leinemann, D.; Goeschen, K. .. 137 Lymphocyte Subpopulations in

Mother and Newborn: Correlation with Sex of the Newborn and Number of Pregnancies

Komlos, L.; Landmann, J.; Notmann, J.; Aloni, D.; Dulitz-

ky, F.; Goldman, J.; Halbrecht, 1143

Selenium Status in Pregnancy: Studies in Amniotic Fluid from

Normal Pregnant Women

Karunanithy, R.; Roy, A.C.; Ratnam, S.S 148

Binding of Levonorgestrel, Norethisterone and Desogestrel to

Human Sex Hormone Binding Globulin and Influence on

Free Testosterone Levels

Nilsson, B.; von Schoultz, B 151

Proposed Management of Low Urethral Pressure Type of

Genuine Stress Urinary Incontinence

Bergman, A.; Koonings, P.P.; Ballard, C.A 155

Endometrial Cyst, Dermoid Cyst and Mucinous Cystadenoma

Sonographically Evidenced in the Same Ovary

Hata, K.; Hata, T.; Kitao, M.; Aoki, S.; Matsunaga, I. .. 160

Original Paper

Changes in Angiotensin-Converting Enzyme during Pregnancy

in the Guinea Pig

Apgar, J.; Everett, G.A

Amniotic Fluid Isoamylase Activity in Uneventful Pregnancies

Goepel, E.; Ulmer, H.U.; Pahnke, V.G.; Schlotfeldt, T.C.;

Bode, F 173

Umbilical Artery Blood Flow Velocity Waveforms and Associations with Fetal Abnormality

Hata, K.; Hata, T.; Senoh, D.; Aoki, S.; Takamiya, O.;

Kitao, M 179

Are Blood Flow Velocity Waveforms Related to Umbilical

Cord Acid-Base Status in the Human Fetus?

Arduini, D.; Rizzo, G.; Romanini, C; Mancuso, S 183

Estriol Reduces the Reactivity of the Human Umbilical Artery

to Mechanical Stimuli

Silva de Sá, M.F.; Salles Meirelles, R 188

Management of Labor in Patients with Idiopathic Thrombocy-topenic Purpura

Dan, U.; Barkai, G.; David, B.; Goldenberg, M.; Kukkia,

E.; Mashiach, S 193

Further Evidence that Prolactin Controls the Prepubertal Sex

ual Development in the Female Rat

Kawagoe, S.; Hiroi, M 197 
Variability of Cortisol and Adrenocorticotropic Hormone Re sponses to Metoclopramide during the Menstrual Cycle

Seki, K 201

Influence of the Maturity of the Vaginal Epithelium upon the Absorption of Vaginally Administered Estradiol-17ß and

Progesterone in Postmenopausal Women

Pschera, H.; Hjerpe, A.; Carlström, K

204

Multiple Serum Markers in Patients with Endometrial Cancer

Benedetti Panici, P.; Scambia, G.; Baiocchi, G.; Perrone,

L.; Greggi, S.; Battaglia, F.; Mancuso, S 208

Prognostic Assessment in Stage I Ovarian Cancer Using a Discriminant Analysis with

Clinicopathological and DNA Flow Cytometric Data Punnonen, R.; Kallioniemi, O.-P.; Manila,

J.; Koivula, T. 213

Preliminary Report

Transvaginal Doppler Color Flow Mapping

Hata, T.; Hata, K; Senoh, D.; Makihara, K; Aoki, S.;

Takamiya, O.; Kitao, M.; Umaki, K 217

Author Index 219

Subject Index 220 